\title{
The Baptism at the Savica by France Prešeren as a Successful Attempt to Outwit Censorship: a Romantic Confession of a Defeated Person, a Member of an Unfree Nation ${ }^{1}$
}

\section{ZORAN BOŽIČ}

\begin{abstract}
Baptism at the Savica, an epic about the loss of Slovenian independence, can also be understood as a successful attempt by France Prešeren ${ }^{2}$ to outwit censors and use the form of a historic tale as a metaphor for expressing the content which, due to censorship, had to be omitted from his elegy Dem Andenken des Matthias Čop. Such an approach can help us resolve several apparent contradictions, shown in the interpretative history of the Baptism, such as the problem of Prešeren's own characterisation of the poem in his letter to Čelakovský, or the question of Črtomir's conversion at the end of the third part of this epic poem.

In the $20^{\text {th }}$ century, several interpretations came into being that understood Črtomir's conversion to Christianity as an inevitable choice made by Slovenians in favour of a stronger, uniquely prospective Western culture circle, which serves as justification for Črtomir's renunciation of freedom-loving Slovenianhood. According to the new understanding of The Baptism at the Savica, there are two Črtomirs, one is the hero and the other is the defeated one (the former, as he himself would like to be, is only an illusion by Prešeren, and the latter, as he indeed is, is the one with whom the poet completely identifies himself), and the final message of the epic poem is understood as a condemnation of national inequality.
\end{abstract}

Keywords: Prešeren, Baptism at the Savica, open work, censorship, interpretation, national inequality

Translated by Darja Teran.

2 France Prešeren (1800-1849) is the most important Slovene poet of romanticism. Although of peasant origin, he completed his doctor's degree in law in Vienna. He worked in Ljubljana as a lawyer's assistant and, due to his free thinking, was permitted by the authorities to open an independent law practice only three years before his death. With his poetry, romantic in content and classical in form (Romance poetic forms, such as tercina, quartina, octava and sonnet, prevail), the Slovenians established a contact with contemporary European literature. Prešeren's poem which is the most wellknown abroad, $A$ Wreath of Sonnets, unites top-level artistry with significant patriotic contents. Prešeren influenced romantic literatures of other South Slavic nations; with the translation of the Poems into Russian, Russian authors revived their tradition of writing sonnets. For more information see Cooper 1981. 
The Baptism at the Savica by France Prešeren

\section{Introduction}

The Baptism at the Savica is a demanding home reading assignment for secondary school students, which is true not only from the point of view of reception, but also because it is a text which has been subject to very diverging interpretations and opposing evaluations, while even the most prominent Slovenian specialists on Prešeren frequently make substantial changes to their points of view (Kos 2001: 81-90). This characteristic of Prešeren's poem has persisted also in most recent times, as it can be concluded from numerous papers written on the occasion of the anniversary of the poet's $200^{\text {th }}$ birthday ${ }^{3}$ (scholars, for example, even disagree whether Prešeren's words in his letter to Čelakovský regarding the metric task and his wish to please the clergy, was meant in an ironic sense or not (cf. Scherber 2002: 207 and Bonazza 2002: 211 on the one hand and Kos 2002: 151 on the other). Therefore, it can be assumed that the diverging interpretations do not stem only from different worldviews of the scholars interpreting the poem and the social and historical changes, but it is a structural characteristic of the literary text itself.

\section{Interpretative Specificity of the Baptism}

A successful incorporation of theoretical findings by modern literary science into the research of Slovenian literature has shown that The Baptism at the Savica is an open work that, with its inner symbolic dimensions and stylistic procedures of high complexity, evades final or even one-sided interpretation (Paternu 1977: 86). ${ }^{4}$ Due to its canonization, antonomasia, the duration and

3 After the remarkably extensive, well-founded and comprehensive study by Paternu, written in 1970 and 1977, it had seemed for a while that possibilities for the interpretation of the Baptism have been more or less exhausted, but events occurring at this anniversary confirm that this is not the case.

4 The Baptism is a romantic poem, consisting of three parts: a sonnet dedicated to Matija Čop, the Introduction, written in tercets, and the Baptism, composed in stanzas. In the Introduction, Prešeren presents Slovenian resistance to Bavarian Christianisation efforts. Valjhun, the Christian army leader, defeats the Slovenian prince Črtomir and kills all his soldiers. This leads to Slovenians losing their national independence for a thousand years. In The Baptism, the defeated Črtomir hopes to make his life meaningful with Bogomila, his fiancée and pagan priestess at the Bled island (the first retrospective depicts their happy meetings). However, during the fighting, Bogomila has converted to Christianity (the second retrospective) and aims to enter a monastery. Consequently, Črtomir must renounce her. At the end of the poem, Črtomir is baptised by the Savica waterfall, expecting to go to Aquilea, a centre of Christianity, and becoming a monk. 
BOŽIČ

intensity of its effect and its encouraging of metatextual series, this poem by Prešeren is a text of key importance, ${ }^{5}$ which with its irresolvable contradictions (displaying themselves as ambivalence, litotes, inconsistency and polysemy), encourages the activity of signification which results in numerous and diverse literary, critical and literary-study-focused metatexts (Juvan 1990: 86-113). This, of course, does not imply that all interpretations of, or references to the Baptism are equally valid, but it is still up to the critical reader to be the judge of that.

\section{Central Contradiction within this Poem by Prešeren}

The basic problem that enables different interpretations and evaluations is without doubt the title motif of the baptism i.e. the fact that Črtomir as the leader of the Slovenians who had fought for the old religion and therefore their own independence, suffers a military defeat, after which, at the end of the epic poem, he converts to Christianity. Janko Kos, who in 2001, two decades after Paternu (1977: 87-94), presents an even more exhaustive history of critiques and interpretations of The Baptism at the Savica, ${ }^{6}$ especially in view of Črtomir's (and also Prešeren's) religiosity, distinguishes between catholic and freethinking interpreters of the Baptism, and in doing so, he also differentiates between moderate, firm and aggressive freethinking.

With younger experts on Prešeren (from 1960 onwards), Kos notices their moderation in interpretation and acknowledgement of the full artistic value of the epic poem, and at the end of his historical overview, he establishes that "the critical and interpretative views have been more or less ultimately harmonized in many issues", such as the fact that The Baptism at the Savica cannot be interpreted as a solid freethinking text, even less as an atheistic text, nor as a distinctively Christian or even catholic text, but rather as intertwining and combining both layers" (Kos 2001: 96).

This article aims at maintaining the interpretative openness of the Baptism and in doing so, elements of the content and message of some other poems by Prešeren are taken into account, as well as the specificity of this poem in comparison with other Romantic texts, the poet's mental and emotional state after the death of Matija Čop in 1835, and especially his struggle with censorship and his proven talent for communicating a message between the

This, more modern term is used by Juvan instead of the "national myth".

6 Due to unknown reasons, both experts on Prešeren omit a very extensive discussion by Puntar's Dante in problem Prešernove "nove pisarije" from 1925. 
lines. I am searching for some new emphases in the literary text itself and I also lean on important, but often overlooked findings by older and newer studies of Prešeren's poetry.

\section{Prešeren's Poems before and after the Baptism}

Even though Prešeren scholars have agreed on the fact that Prešeren was a freethinker who could be considered externally affiliated to Christianity only by way of exception (Kos 2002: 150), ${ }^{7}$ some scholars, however, due to Črtomir's conversion, attribute to the poet and his work an expression of the Christian worldview: "In his poems, Prešeren has clearly and strongly expressed his Christian conviction. ${ }^{8}$ Indeed all of his poetry, which does not bear even a trace of hypocrisy, grew from a firmly religious heart. Particularly his Baptism at the Savica, with the beautiful sonnet dedicated to Matija Čop, is a magnificent piece of evidence of his Christian mindset." (Lampe 1899: 482)

Exactly the opposite path has been taken by those who, by analysing other important poems by Prešeren (e.g. A Farewell to My Youth, Sonnets of Unhappiness and To the Poet - Košir 1977: 127), deny also the Baptism the character of an apology of Christian faith. Proof that the poet's intimate relationship to the hereafter was not any different when he was writing the Baptism, is provided by the poems Cure for Love and Fisherman and especially by the ballad Reburial, where a poet commits suicide due to unrequited love and afterwards, when he is mistakenly buried with a church ceremony in consecrated ground, he himself demands to be reburied among the bandits and as an excommunicate, he accepts the impossibility of redemption.

An argument against the theory that, after the death of Matija Čop, Prešeren began to accept basic attributes of the Christian faith in order to solve his existential distress, is ultimately provided by the ballad The Still Beating Heart from 1845, in which the author points to the difference between the Christian holiness and the poetic holiness, since the poet Dobroslav, after his love has been rejected, leads a dissolute life in breach of Christian moral norms and immortality is not granted to him by God, but by poetry. A similar existential relationship is attested through events accompanying the publication of the Poems collection in 1846, when Prešeren first intended to add his German

7 "There are many well-known facts which prove that Prešeren's Christianity was merely external - his anticlerical statements, refraining from attendance at worship in his older years, his not receiving the Sacraments, more frequent attendance at Mass during his last years, confession with Communion and Anointing on his deathbed."

8 Underlined by F. L. 
BOŽIČ

poetry to the Slovenian poems and right at the end of the collection, he wanted to place the sonnet "Wohl ihm, dem fremd geblieben das Erkennen" ("Oh, Happy the Man Who Remained a Stranger to Cognition”) from 1833, which "contains the recognition that creating poetry in a world as it surrounds him is an action without any meaning, it is pure absurdity," therefore, in this poem, "Prešeren's despair has reached its limits" (Paternu 2002: 190).

\section{The Baptism at the Savica and Romantic Narratives from Other Countries}

The fact that with the Baptism, Prešeren did not write a national epic, especially not an epic that would establish and strengthen the Slovenian national authenticity based on the defeat of paganism and the transition to Christianity, is confirmed by problems faced by this poem as far as its reception by readers is concerned (it became obvious "that the Baptism really is somewhat problematic for establishing a nation, which seems to have been expected from an epic poem in those times and also later" - Hladnik 2002: 191), ${ }^{9}$ and its unusual or disparate character is confirmed by comparing it to some thematically similar Romantic narratives from other countries.

In the history of literature, there are some similarities in motif and theme between the Baptism and the Romantic tragedy Das Kreuz an der Ostsee from 1806 (Kos 1991: 158-160). ${ }^{10}$ The German playwright Werner later even became a Catholic priest, but in his dramatic text, "the Polish are presented in a negative light, although they were Christians, and the pagan Prussians are positive characters" (Bonazza 2002: 215). A comparison to this text which might have directly influenced the formation of the Baptism's plot reveals a similar relation of values between the domestic paganism and the foreign Christianity such as in Prešeren's poem.

Just like the Baptism, also two other South Slavic poems of the Romantic era, The Death of Smail-aga Čengić by Mažuranić and The Mountain Wreath by Njegoš deal with the problems of nationality. "In all three poetic texts, the national idea or rather the idea of 'national liberation' is directly connected to the religious ideas. While with Mažuranić and Njegoš, there has been a full identification of the religious with the national, although with different

9 Hladnik adds in a footnote: "Tugomer by Levstik is the first known correction of the problematic hero of the epic.”

10 This is the national and religious conflict between paganism and Christianity and the motif of the heroine makes a vow to God in order to save the life of her lover, a motif of denouncing earthly happiness and the Romantic motif of a small island. 
concretisations and consequences, there is a sharp separation between the religious and the national as Prešeren and faith itself is questioned." (Martinović 2002: 92)

\section{Prešeren's State of Mind in 1835}

Existing studies on Prešeren have so far provided a sufficiently detailed description of the poet's state of mind in the year when he was writing the Baptism and also of the reasons for this condition, where a century ago, "when difficulty upon difficulty, resentment upon resentment, misfortune upon misfortune were crashing onto the sovereign path of his soul and finally carried away the strongest and dearest support - Matija Čop" was described even as a "psychic catastrophe" (Prijatelj 1952: 343-344). His friend's death was, of course, the immediate reason why the poem was written, but even before that the poet's attitude to life was marked by two events: his second application to become an independent barrister had been rejected and Julija Primic became secretly engaged to Jožef Scheuchenstuel (Kidrič 1938: 275).

Both events are directly connected to the content and message of The Baptism at the Savica, the former because it became clear to the freethinking and rebelliously self-confident poet, who liked to say that "a free man does not wear a yoke" (Paternu 1976: 18-20,28), how hard it was in those socio-political circumstances to attain professional independence, and the latter because Julija's engagement to a German and a nobleman made him realise that, due to his nationality and also his social position, his chances in love were limited.

\section{Prešeren's Struggle with Censorship}

It is an extremely important fact that The Baptism at the Savica passed through the ordeal of censorship, in spite of having in its Introduction the wide set verse More of the world is Slava's sons or later the verse Bright fortune shines on aliens in our homes, ${ }^{11}$ even though the words used by the priest to speak about the equality of man at the end of the poem are almost the same as the words in A Toast which was censored a decade later. Therefore the Baptism "was, in the eyes of the authorities, a politically and morally innocent word, unlike the poem

${ }_{11}$ In the secondary school reader by Sket, even after 1900 this verse still reads Bright fortune shines on victors in our home. 
BOŽIČ

Seven Sons" (Hladnik 2002: 194). ${ }^{12}$ Certainly it should be borne in mind that all three official persons making the decision whether or not to issue a permit to print the Baptism were Catholic priests, and the delegated governorate censor Gollmayr later even became a long-standing Prince-Archbishop in Gorizia (Žigon 1925: 280-281).

Prešeren's experience with the censorship on the district and state level was completely different; especially well known are the problems experienced by the literary almanac Krajnska čbelica in the early eighteen-thirties (Kidrič 1938: 308-316). A Wreath of Sonnets could be published only because "the censorship of local newspapers was then carried out by the worldly-minded Vesel who, in spite of all his conservative predispositions, was still a much more liberal censor than an officer from the ranks of priests" (Kidrič 1934: 122).

Prešeren suffered the most severe blow when, soon after Čop's death, the censors Pavšek and Stelzich crossed out five crucial tercets from the poem Dem Andenken des Matthias Čop. It is the "compositional focus of the poem" which "carries a special weight of meaning", a protest "against presumptuous rulers who do not know a man's true value and therefore the endeavours of the best men are in vain" and it also deals with the "problem of supressing one's Slovenianhood and degrading oneself to serve another language, which was of course German"13 (Paternu 1977: 77-78). The extent to which the poet was offended by this is most clearly shown by his protest sonnet with the acrostic An Pauschek und Stelzich, which he sent to the two censors to be published in the following issue of the Illirysches Blatt newspaper, of course to no avail. At the beginning of the tercet part of this sonnet, he wrote Away, when I am all torn apart by pain!, and he calls them wolves of the choir loft (they were both canons) and at the end of the sonnet he even predicts their death.

\section{Communicating Messages between the Lines}

Prešeren is said to have been a very bright and rational person who also had a good sense of ironic distance (Paternu 1976: 14-17). Proof of such personal characteristics can be found in his "Little Riddle" (the solution of which is c a s ino), but also in some other poetic texts such as the epigram "Prologue and Defence" at the beginning of his Satirical Writings, where he attributes importance to the people who are targets of his poetic arrows, while putting

12 The tale in verse Seven Sons of the priest Jožef Želja had to wait for two whole years to be approved by the censors.

13 According to Paternu, Prešeren "has never and nowhere expressed this problem so sharply as in the elegy to Čop, written in German”. 
himself in the place of God. In the Poems which were published in 1200 copies, most copies had some words changed in the "Master Sonnet", and only 150 of them - the ones that were destined for Prešeren's friends - had the acrostic PRIMICOVIJULJI preserved. For tactical reasons, in the censored copy of the sonnet "To Pauschek and Stelzich" the word Chorwölfe (wolves of the choir loft) was exchanged for the word Christlich (Christian) (Puntar 1925: 218). A play on words can also be found at the end of the famous sonnet "When Apelles Exhibits his Painting" and a poetic tactic of a hidden message can be found even in "A Toast".

Since Prešeren was aware of the fact that "A Toast" might encounter problems with censorship, (this is why he himself left out the third strophe), instead of the text in the seventh strophe he chose No war, no strife shall hold its sway instead of there shall be no enslaved head beneath him!, and a similar motif was included in the ending of the strophe Who long to see / That all men free / No more shall foes, but neighbours be! (Paternu 1977: 243). By doing so, Prešeren concealed his original demand for social and national equality, and this is why today some interpreters of the now Slovenian national anthem read it as an appeal for a peaceful coexistence of nations, although the poet consigns this wish to a distant future and the present time, which is mentioned in the previous strophes, calls for a national emancipation and therefore a conflict with those who oppress the Slovenian people. Because of this there is reason to believe that Prešeren used his abilities to communicate a message between the lines also in The Baptism at the Savica and thus ensured approval by the otherwise disinclined censors.

\section{Baptism at the Savica with a Double Textualization Strategy}

Assuming that, in the Baptism, Prešeren attempted to use his narrative strategy (or rather a declarative strategy, since this text is closer to an elegy than to a national epic), which would enable him to design and form the content in a way that would safely avoid the obstacles of Catholic censorship, but at the same time express these exact thoughts that were not allowed to be published in the elegy “Dem Andenken des Matthias Čop" (Žigon 1906: 110-120; Puntar 1925: 196234; Kidrič 1925: 692-693; Slodnjak 1984: 287-294), this paper supplements and deepens its author's interpretation of The Baptism at the Savica, entitled Tri Prešernove krivde (Three Kinds of Prešeren's Guilt, Božič 1993).

In order to be able to successfully reach the set objective, the poet had to think of a story, the plot and story line of which would as much as possible correspond to the Catholic ideological orientation of the censors, but he also 
BOŽIČ

had to build several indicators into it, that would explain to a critical reader what was the author's true opinion of the problem and the final message of the poem. As can be seen from the way the poem was received, the first part of his plan was a complete success, and the second part was decisive for keeping the poem alive still today, as it presents a constant challenge for interpretation.

\section{A Poem as an Expression of National Inequality}

The sonnet dedicated to Matija Čop indicates that The Baptism at the Savica is a metaphor for Prešeren's personal declaration of his life (Šifrer 1935: 386; Slodnjak 1964: 184; Paternu 1977: 83/84), and there is also a direct connection between the textual world of poetry and the poet's life in A Wreath of Sonnets. There, Prešeren is asking Julija Primic for her affection: with her kindness, his poems would acquire an Orphic power with which Slovenians would become conscious of their nationality and be reunited ${ }^{14}$ (Paternu 1976: 266). After Čop's death, Prešeren became clearly aware of the fact that his project of rebirth from $A$ Wreath of Sonnets had failed, even more, that the authorities, disinclined to Slovenians and Slovenianhood, were censoring each and every more resolute poetic statement, so it could be perfectly understandable that he wrote in his letter to Čelakovský: "As the most wavering reed in the desert of Carniolan literature, I would raise my voice as another John to announce the Messiah, but the Pharisees and the scribes do not let me speak ...” (Prešeren 1964: 336)

Therefore, it is entirely logical that the beginning of The Baptism at the Savica is some sort of a continuation of the problem dealt with in A Wreath of Sonnets. Crtomir, as the last warrantor of a free Slovenian nation, indeed has an Orphic power of persuasion and, as a Romantic hero, he leads all of his soldiers into battle, ${ }^{15}$ but due to the superior forces of the enemy, a defeat is inevitable. To illustrate, I refer to the part of the "Introduction" that presents Črtomir as a fighter for the freedom of his nation:

14 This association of thoughts is deeply disharmonic, since the poet is not satisfied by putting the rich bourgeois girl in juxtaposition to his own poetic genius, but he underpins his expectations in love with the fate of the entire Slovenian nation (Božič 1993: 319).

15 Črtomir seemingly grants his fellow fighters the possibility to surrender, but in a distinctly demagogical speech (moral, psychological and ideological pressure) he convinces them that it is better to risk trying to break out of the fort (Božič 1993: 319$320)$. 
What sword and ax and shovel failed to do, That hunger, the unconquerable foe

Now threatens, as it weakens men's resolve.

No more can Črtomir their plight conceal, These words he speaks to all his gathered troops:

"No sword, but bitter fate will bring us down.

So little food remains for you, my brothers.

We've fought so long with no hope of support.

Who wants to yield, I will no longer stop him.

Who of you wishes to await dark dawn, To live enslaved days similar to nights, I'll stop him not, just let him wait for morn.

The heroes of you I now call with me, All you whose backs unwilling are to bend; The night is dark and thunder shakes the clouds.

The enemy will scurry to their huts, The forest is no distance from our walls, And night gives us a chance to flee the fort.

More of the world is Slava's sons, by right, And we will find the pathway to that place Where they may cherish faith in liberty.

But should the gods decree us then our death, Less fearful is the night in black earth's womb Than days of slavery here beneath the sun."

Not one man quits him in his time of trouble, In silence each his weapon brings to bear, And not a coward has he in their number.

No sooner, though, than are the gates swung wide But there begins a battle, no, a slaughter:

Valjhun with his whole army falls upon them. (Prešeren 1996: 18-22) ${ }^{16}$

16 Translated by Henry R. Cooper Jr. 
His fellow-fighters believe without exception that death is better than slavery and this is why all of them fight fanatically, even after the possibility of their common escape has vanished. ${ }^{17}$ At the end of the Introduction, it turns out that Črtomir is the only one who has managed to escape and the poet himself accuses him for this (Martinović 2002: 106). The moment when the gates are opened and also he, to be true to his own words, ought to fight until the end as a Romantic hero, brings an unexplained turning point ${ }^{18}$, Črtomir flees and thus betrays his own soldiers (only later in the Baptism, we are told that the thought of Bogomila was what drove him out of the turmoil of battle). Črtomir is the only survivor, but he is not a hero anymore, he is defeated.

While in the Črtomir from the Introduction, one can recognize only the utopian Orphic Prešeren who never existed, the poet has much more in common with the Črtomir from the Baptism. By being defeated in the Heathens' Fort, Črtomir has lost his freedom, his companions, his possessions and his high standing in society, and this state of being unfree, lonely, poor and insignificant, mirrors Prešeren's existential situation at the time after the death of Matija Čop. In the moments when Črtomir is plagued by suicidal thoughts (but he, of course, as a defeated one will not commit suicide), he has become exactly what he predicted in the Introduction for the case of surviving the defeat: a slave, a vassal, an underdog. Facing Valjhun's attested cruelty (Christian soldiers also killed all wounded pagan soldiers and, according to a fisherman, they were still killing and torturing the captured pagans), he should consider himself lucky if he stayed alive by taking on a new religion.

Prešeren, who slaves at Crobath's office for a small amount of money, who, by adverse authorities, is forbidden to become an independent barrister and to publish his texts, who is without supporters and allies even among Slovenians, is of course aware of the fact that the beloved girl from a respected urban family cannot belong to him as a social underdog. This is why the defeated Črtomir, after Bogomila's arrival at the Savica waterfall (although, pursuant to his new position, he degrades himself and is absolutely subordinated to his fiancée who was once his equal), experiences one blow after another, and finally he accepts the baptism in silence and his mission as a priest, which will enable him to survive in a physical sense, but at the same time is a complete opposite to and negation of the ideals of Črtomir the hero.

17 On average, each pagan warrior killed five Christian opponents.

18 This turning point, which has caused headaches for numerous interpreters, is not explained or reasoned by Prešeren, as it was absolutely correct not to do so, since the narrative is not psychologically realistic but metaphorical. 
More information about the hidden message of the Baptism can be obtained by carefully observing four crucial scenes in the love story of Črtomir and Bogomila. At the first meeting of the young army leader and the even younger priestess, Prešeren describes their mutual infatuation in a poetically efficient manner.

A light and little boat brings Črtomir

To offer gifts to Živa, as his wont was,

Of all that grew about his land and castle,

Of flocks and grain and first fruits of the garden.

As he presents them to the fair young maid,

Love's arrow flies from her eyes to his heart

And strikes him when he least expected it.

The flame of love is kindled in his breast.

O happy, happy Črtomir, you've won

The maiden with your glance, and that alone.

And she is overcome with ecstasy,

Her gaze is earthward, trembling are her words,

Just like a dawn that promises fair day.

And her pale face appears to colour slightly,

The while her hand remains enclosed in yours,

Kept there by powers she cannot command. (Prešeren 1996: 38-41)

Also at their farewell after one year of happiness, the lovers are united in a long kiss, they are like one body and they are both crying.

How hard, how bitter is the hour of parting!

Great tears are running down their burning cheeks.

Entwined they stand as if they were one body

Nor will allow their clinging lips to part.

A drop now from the right, now from the left eye

Her father is unable to disguise,

As he regards them plunged into such sorrow,

And knows there is no consolation for them. (Ib. 42)

When they meet again at the waterfall, Bogomila backs away from him and sits down on a stone.

"O, hither to my heart, my Bogomila!

The end of worry, woe and grief is here.

Each fibre of my being moves with joy 
BOŽIČ

As I behold the radiance of your face.

So let the whirlwinds loose now all their fury, The heavens be covered over by their clouds. It matters not to be me what happens now, As long as you are in my happy arms."

Reluctantly she leaves his fond embrace, And comes to rest upon a rock nearby, And in a firm but loving voice addresses The ardent youth with words she has to say: "Now is the time of parting, not of union, And each must make his own way through life's snares. So that eventually our paths should cross, You see me now in this forsaken place.” (Ib. 57)

At their final farewell, the disappointed Črtomir is crying while Bogomila's face lights up with joy.

When it was finished, thought he of his gold, And took some from the man who'd brought it to him.

The rest he left the fisherman and them.

"As for the trove, tell Staroslav to give

The orphans help," says he to Bogomila, Then went to her and held her fervidly. He silently a hand gave in farewell, And tears stood in his eyes as he departed. [...]

In silence Črtomir bends to hear will, And to Savica's falls they make their way. He with the priest repeats the sacred prayers, And, Father, Son, and Spirit, is baptized there. All who are there fall down upon their knees, The maiden's face lights up with heavenly joy, The face of her who'd served a pagan faith, And once had worshiped as a priest of Živa. (Ib. 88-91)

In the first two scenes, there is amorousness and equality and in the last two scenes, there is estrangement and inequality. A key to understanding the meaning of such a narrative is the fact that the first two scenes take place in the past, when Črtomir was a hero, and the last two scenes take place in the present time, when Črtomir is the defeated one. In between, there is the clash of arms between the pagans and the Christians and the defeat at the Heathens' Fort. 
Even though many scholars have pointed out Prešeren's identification with Črtomir, the fact which received less attention was that the poet is capable of identifying himself only with the defeated Črtomir, but he never feels a similarity between him and Črtomir the hero, the eager-to-fight Črtomir from the Introduction and the happy Črtomir from the first retrospective.

Let other poets tell you of the love

That all that summer blossomed in their hearts:

Of Črtomir's oft visits to the temple,

Of father's growing younger as he watched them

To me unknown but not to others joy

Is that which brands the heart with happiness.

Let others tell of love's intoxication,

Soon driven away by fear of separation. (Ib. 41)

Before the beginning of the Baptism and after the defeat, a crucial change is not only in the victory of a new, Christian religion, but also in the loss of Slovenian independence. This means that Prešeren can only relate to the Črtomir who, as a Slovenian in circumstances of national inequality and subordination to other nations, "owns nothing, is worth nothing, is nothing". ${ }^{19}$ Or if we transfer Črtomir's life story to modern times and turn the relationship around: Prešeren's hidden message in The Baptism at the Savica is that the reason for his situation of an unfree, lonely, poor and insignificant poet is the Slovenian subordination to other nations and thus national inequality. If, in 1835, the Slovenian nation would be independent, which was the long-term project of $A$ Wreath of Sonnets, Prešeren would have been an important national poet who would then be able to work conscientiously to acquire solid assets, which would inevitably make it possible for him to hope for a beloved girl from a respectable urban family.

\section{Conclusion}

At the end, let us take a look at the riddle of the sonnet dedicated to Matija Čop.

To you, dear ashes of a friend who sleeps

In a too early grave, I give this song.

In parting from him it has been a balm,

A tonic for a bygone, wounded love.

19 These words are taken from the letter by Kvas to his friend Ferdinand Bojan (The Tenth Brother by Jurčič). 
BOŽIČ

Proclaim the passing of the world's sweet ties,

How small the number of our happy days,

That only he, like Bogomila, thrives,

Whose heart awaits its joy beyond the grave.

I've buried all my high-flying thoughts

And all the pains of unfulfilled desires,

Like Črtomir all hope of earthly joy;

Bright day, dull day, they both become our nights,

And riven hearts which suffer joy and pain

Will calm find in the deepness of the grave. (Ib. 9)

There is no doubt that, according to Prešeren, the people who, like Bogomila, believe in happiness after death, are fortunate. There is also no doubt that Prešeren thinks that Črtomir has abandoned any hope for this-worldly happiness, for the happiness here and now. But what remains somewhat hidden is the fact that Prešeren identifies himself with the Črtomir who has "buried all his high-flying thoughts and all the pains of unfulfilled desires", therefore he identifies with the defeated Črtomir. This is why The Baptism at the Savica can only be a tale of defeat and a statement by someone who has been defeated.

\section{Zoran Božič}

zoran.bozic@guest.arnes.si

Fakulteta za humanistiko

Univerza v Novi Gorici

Vipavska cesta 13

5000 Nova Gorica

SLOVENIJA

\section{References}

Bonazza, S. 2002. Krst pri Savici in vprašanje Prešernove ideološke orientacije. M. Juvan, ed., Romantična pesnitev: ob 200. obletnici rojstva Franceta Prešerna. Ljubljana: Filozofska fakulteta, 211-221.

Božič, Z. 1993. Tri Prešernove krivde: interpretacija Krsta pri Savici. - Sodobnost, 41/3-4, 318-322.

Cooper, H. R. Jr. 1981. France Prešeren. Boston: Twayne.

Hladnik, M. 2002. Dve povesti v verzih iz prve polovice 19. stoletja. - M. Juvan, ed., Romantična pesnitev: ob 200. obletnici rojstva Franceta Prešerna. Ljubljana: Filozofska fakulteta, 189-202. 
Juvan, M. 1990. Imaginarij Krsta v slovenski literaturi: medbesedilnost recepcije. Ljubljana: Revija Literatura.

Kidrič, F. 1925. Dante 1321-1921. - Ljubljanski zvon, 45/11-12, 629-633; 691-694.

Kidrič, F. 1934. Situacija ob prvem natisu Sonetnega venca. - Ljubljanski zvon, 54/2, 119-122.

Kidrič, F. 1938. Prešeren II: biografija 1800-1838. Ljubljana: Tiskovna zadruga.

Kos, J. 1991. Prešeren in njegova doba. Koper: Založba Lipa.

Kos, J. 2001. Krst pri Savici v luči kritik in interpretacij. - In F. Prešeren, Kerst per Savizi. Celje: Mohorjeva družba, 71-96.

Kos, J. 2002. Prešeren in krščanstvo. - J. Faganel and D. Dolinar, ed., France Prešeren kultura - Evropa. Ljubljana: ZRC SAZU, 149-158.

Košir, N. 1977. France Prešeren. Ljubljana: Partizanska knjiga.

Lampe, F. 1899. Dr. France Prešeren. - Dom in svet, 12/16, 481-485.

Martinović, J. 2002. Južnoslavenski epski triptihon - Pokušaj usporednog čitanja Prešernovog Krsta pri Savici, Mažuranićeve Smrti Smail-age Čengića i Njegoševog Gorskog vijenca. - J. Faganel and D. Dolinar, ed., France Prešeren kultura - Evropa. Ljubljana: ZRC SAZU, 89-110.

Paternu, B. 1976-1977. France Prešeren in njegovo pesniško delo 1-2. Ljubljana: Mladinska knjiga.

Paternu, B. 2002. Prešernova osvoboditev poezije in duha na Slovenskem. - J. Faganel and D. Dolinar, ed., France Prešeren - kultura - Evropa. Ljubljana: ZRC SAZU, $185-192$.

Prešeren, F. 1964. Poezije in pisma. Ljubljana: Mladinska knjiga.

Prešeren, F. 1996. The Baptism on the Savica. Trans. by H. R. Cooper, Jr.. Bilje, Slovenia: Studio RO -Založba Humar d.o.o..

Prijatelj, I. 1952 (1905). Drama Prešernovega duševnega življenja. - A. Slodnjak, ed., Izbrani eseji in razprave I. Ljubljana: Slovenska matica, 315-362.

Puntar, J. 1925. Dante in problem Prešernove "nove pisarije”. - A. Res, ed., Dante 1321-1921. Ljubljana: Kleinmayr \& Bamberg, 93-260.

Scherber, P. 2002. Od metrične naloge do nacionalne epopeje: nekaj opomb k periodizaciji in kanonizaciji Krsta pri Savici. - M. Juvan, ed., Romantična pesnitev: ob 200. obletnici rojstva Franceta Prešerna. Ljubljana: Filozofska fakulteta, 203210.

Slodnjak, A. 1964. Prešernovo življenje. Ljubljana: Mladinska knjiga.

Slodnjak, A. 1984 (1949). Prekop - Krst pri Savici - Neiztrohnjeno srce. - F. Bernik, ed., France Prešeren. Ljubljana: Slovenska matica, 277-319.

Šifrer, T. 1935. Čop in Prešernov Krst pri Savici: 1835-1935. - Ljubljanski zvon, 55/6, 377-396.

Žigon, A. 1906. Tercinska arhitektonika v Prešernu. - Zbornik Slovenske matice 8. Ljubljana: Slovenska matica, 58-128.

Žigon, A. 1925. Krst pri Savici v cenzuri. - Dom in svet, 38/8, 278-283. 